Informasi - ISSN (p) 0126-o650; ISSN (e) 2502-3837

Vol. 49, No. 2 (2019), pp. 125-144 doi: http://doi.org/10.21831/informasi.v49i2. 27989

\title{
THE POLITICAL COMMUNICATION PROCESS AMONG CHINESE MOSLEM SOCIETY
}

\author{
Ulfah Hidayati \\ ulfah.hidayati@uny.ac.id \\ Kurikulum dan Teknologi Pendidikan, Fakultas Ilmu Pendidikan \\ Universitas Negeri Yogyakarta, Indonesia
}

\begin{abstract}
This study aimed to find out the political communication process occurring among the electorates in making decision of electing. In detail the source of information is known to be used for concerning the Pilgub DKI Jakarta of 2012, type of information obtained, and electing decision making among the Chinese Moslem community of Masjid Lautze Jakarta. Output of research was knowledge about the political communication process occurring until the electing decision making.This research referred to the conception that communication is a process of delivering message to exert effect (in this case the electing decision). The mass media effect theory was used as one of references in this research because the mass media pertained directly to the communicant in political communication process. The method used was qualitative one using in-depth interview technique for collecting data with 14 informants from the Chinese Moslem community of Masjid Lautze Jakarta. From the research it could be found that the dominant information source used to access the political information was mass media (television and newspaper), BBM (Black Berry Messenger), interpersonal communication media, group communication media, and other information source such as outdoor advertisement. Meanwhile in the term of information type, the information on Jokowi-Ahok couple became the most widely obtained one by the members of society. The electing decision was generally affected by such factors as mass media, interpersonal communication, group communication, organization, and observing Jakarta's condition directly. The opinion leader factor (ustadz and foundation leader) did not have influence in this research.
\end{abstract}

Penelitian ini betujuan untuk mengetahui proses komunikasi politik yang berlangsung pada khalayak pemilih dalam pengambilan keputusan memilih. Secara detailnya diketahui sumber informasi yang digunakan untuk mendapatkan informasi mengenai Pilgub DKI Jakarta 2012, jenis informasi yang didapatkan, dan pengambilan keputusan memilih di kalangan warga muslim Tionghoa jama'ah Masjid Lautze Jakarta. Output dari penelitian ini adalah pengetahuan mengenai proses komunikasi politik yang berlangsung hingga samapai pada tahap pengambilan keputusan memilih. Penelitian ini mengacu pada pemahaman bahwa komunikasi adalah suatu proses penyampaian pesan yang akan menghasilkan efek (dalam hal ini keputusan memilih). Teori mengenai efek media massa digunakan sebagai 
salah satu acuan dalam penelitian ini karena media massa langsung bersinggungan dengan komunikan dalam proses komunikasi politik. Metode yang digunakan adalah kualitatif dengan teknik pengumpulan data menggunakan in-depth interview pada 14 narasumber warga muslim Tionghoa Jama'ah Masjid Lautze Jakarta. Dari penelitian tersebut didapatkan sumber informasi dominan yang digunakan untuk mengakses informasi politik adalah media massa (televisi dan koran), BBM (Black Berry Massanger), media komunikasi interpersonal, media komunikasi kelompok, dan sumber informasi lainnya seperti iklan luar ruangan. Sedangkan untuk jenis informasi maka informasi mengenai pasangan Jokowi Ahok menjadi informasi yang paling banyak didapatkan oleh warga. Untuk keputusan memilih secara umum dipengaruhi oleh beragam faktor yaitu oleh media massa, komunikasi interpersonal, komunikasi kelompok/organisasi, dan melihat kondisi Jakarta secara langsung. Untuk faktor opinion leader (ustad dan pimpinan yayasan) justeru tidak berpengaruh dalam penelitian ini.

Keywords: Political Communication, Communication Process, Electing Decision

\section{INTRODUCTION}

In Indonesia, Tionghoa used to have different treatment in politics. The Orde Baru government discriminatory policies who hide behind a pretext assimilation real failure example is a regime in treating minorities. Michael williams in Afif (2012) 1965, said that after especially after the military under the Orde Baru power, Soeharto discrimination against Tionghoa people felt.

The dynamics of identity in indonesia Tionghoa are strongly associated with shades of a political policy, ruler where they have to put the interests of certain Tionghoa in accordance with his political willpower. Minority positions that tend to vulnerable, always cornered Tionghoa from time to time (Eriyanti, 2006).

1965 tragedy remaining the deep sadness among Tionghoa people in Indonesia. Resentment the government against Tioghoa related to PKI (Communist Party) ransmitted to the people massifly, that broke the riot anti-tionghoa in major cities in Indonesian. Hundreds of lives drift in the riot. It is not over yet, Indonesian government then officially issued total policy assimilation for the Tionghoa which includes almost all aspects of life, starting from education, language, citizenship, economic , and also religion.

Tionghoa issues (Suryadinata, 2010) much caused by a negative perception of the
Tionghoa. As solution to address the problem of Tionghoa in the context of creating national integration, the government apply wisdom assimilation. Assimilation for Tionghoa ethnic means being included in local culture, so that the characteristics of typical as Tionghoa do not exist anymore (Kodiran, 2012).

Then, Afif (2012) said that the emergence of the era of Reformasi was expected to create a more democratic political must be redeemed at the riot of May 1998, again made Tionghoa as the victims. It is in the long list of acts of violence against the Tionghoa in this country.

Power or politics granting influence on Tionghoa ethnic to identify themselves associated with their cultural identity, if order in the Order Lama and Orde Baru era Tionghoa tend to be afraid to articulate their identities, but in the days of reform inclined to articulate their identity through various forms of representation.

The identity of Tionghoa have only just started to sent back in the days of reform that is driven through the Presidential Decree of the Republic of Indonesia no. 6 in 2000 that pluck out Presidential Instruction no 14 in 1967. In the days of reform up to now, Tionghoa ethnic identity dare show their culture through various cultural activities that is displayed openly and in front of 
common as Tionghoa new year celebration, passing a new opening Tionghoa schools such as the Bahoa school, through the establishment of an association of various Tionghoa clan and organization, through the Tionghoa mass media as Guoji Ribao, daai tv (Christian, 2017).

In Jakarta governor election in 2012, the participation of Tionghoa people (Basuki T Purnama) as a candidate of local deputy head approved that the existence of Tionghoa in politics acknowledged. Formerly, Tioghoa involvement in political domain has been running since 1932 with the establishment of the Partai Tionghoa Indonesia/Indonesian Tionghoa Party (PTI).

According to Darini (2008), Indonesia Tionghoa Party (PTI)that was established in 1932 is an example of Tionghoa ethnic community who were of foreign descent that has political and economic partiality on indonesia. PTI has clearly identify their self as Indonesian citizens and having awareness to fight alongside the political parties at that time to fight for the independence and nationalism of Indonesia.

As stated Ilyas lampe, that identity ethnic usualy done to the community multiethnic always directed on the situation and the context in which a person is. Ethnic identity is the important issue in political activity. Ethnic identity is something that problematic when faced with political communication, especially in democratic election system. It can be distinguishing or co-identify to parties who use them for the purpose of to political support (Lampe et al., n.d.).

In this research, nuslim Tionghoa are taken as an object research because they are considered have an interesting decision, considering they are Tionghoa and muslim. Of course by their position that has two double function (muslims and Tionghoa) ,there a chance for them to have a decision that more unique compared to Tionghoa people in general.

The Karim Oei mosque or better known as the Lautze mosque, located in Jl. Lautze
Raya, Pasarbaru, Central Jakarta became one of the history symbols for Muslim Tionghoa in Jakarta. At least this mosque have kept history two different cultures, namely islamic culture (native) and Tionghoa cultures living side by side since tens of years ago. The Tionghoa muslim community in Jakarta grouped in jama'ah (member) of Lautze mosque is Tionghoa muslim populations live in Jakarta and neighboring areas. On Governor election in 2012 Muslim Tionghoa populations of these communities also have voting rights.

This research aims to understand how political communication in decision making pick muslim populations of Tionghoa of jama'ah Lau tze mosque in Jakarta governor election in 2012. The political communication process in this research seen through some of communication pattern such as, interpersonal communication, communication a group or organization, and mass communication.

\section{LITERATURE REVIEW}

\section{Political Communication}

Political communication is the process of delivering information about politics from the government to the community and from the community to the government (Surbakti, 1992: 199). The function of political communication is carried out by all members of political parties as active participants in political parties and also communicators in conveying the contents of information or messages. Here they as communicators must be able to convey the information appropriately to the audience or listener, so there is no miscommunication from top to bottom (Amirudin, 2016)

Still mentioned by Amirudin, (2016) political communication likes as blood, flowing political messages in the form of demands, protests, and support (aspirations and interests) to the heart (center) of the processing of the political system and the results of processing, which are knotted in functions out put, re-streamed by political communication which subsequentlybecomes 
the political system feedback (Alfian, 2013). Thus, political communication makes the political system alive and dynamic. In other words, political communication connects all parts of the political system, and also the present with the past, so that aspirations and interests are converted into various policies. Where the communication runs smoothly, naturally and healthily, the political system will achieve a high level of responsive quality to the development of people's aspirations and interests and the demands, changing times. Alfian further described the important role of political communication in maintaining and improving the quality of reliability of an established political system. Political communication transmits political cultural values that originate from the worldview or ideology with the community to the new generation (children, adolescents, and youth), and strengthens the process of culture in the older generation (Alfian, 2013).

\section{Mass communication}

Communication in the context of mass, or commonly known as mass communication, has been widely defined academics. Among them stated by Bittner, that mass communication is a message that is communicated through mass media to a large number of people (Mass communication is messages communicated through a medium to a large number of people) (Tan, 1985: 176). This definition implies the meaning that mass communication is essentially a process of communication carried out by a mass media organization to a broad, anonymous audience. Littlejohn called such a communication process with the concept of media encoding, which is the process by which media organizations provide their messages to the public. (Imran, 2013)

Dennis McQuail said that the communicator in mass communication is not one person but a formal organization. Mass communication creates wide influence in a short time to many people simultaneously. One of the communicators in mass communication is mass media. The mass mediahasthecharacteristicsorcharacteristics that are able to reach the mass in large and broad numbers (universality of reach), are public and able to provide popularity to anyone who appears in the mass media. These media characteristics have consequences for contemporary political and cultural life today. From a political perspective, the mass media has become an important element in the process of democratization because it provides an arena and channel for public debate, makes potential political leaders widely known to the public and also plays a role in disseminating various information and opinions (McQuail, 2011).

\section{Interpersonal Communication}

Interpersonal communication and media played an important role during the December 2012 elections to the National Assembly. On one hand, they are served as traditional and modern platforms for people to seek and exchange political information and opinions. On the other hand, the government used both forms of communication as instruments to restrict freedom of expression (Human Rights Watch, 2013; Reporters Without Borders, 2013) and to maintain political stability in the country. The present study determines the extent to which the Kuwaiti citizens who responded to our survey were exposed to political news and advertising and engaged in face-to-face discussions about the December campaign. Credibility ratings were also obtained for each source.

Interpersonal communication was measured as time spent on a regular weekday during the December 2012 election campaign talking with other people (e.g., relatives, friends, coworkers, and other community members) about the parliamentary election. Respondents rated time spent using the same scale from "Half an hour or less" to "Three hours or more." (Kononova \& Akbar, 2015)

\section{Organization Communication}

Communication managers in public sector organizations operate in increasingly complex environments. An influential political realm, diverse stakeholder 
environments, and media scrutiny combined with macro-level developments in the public sector put high demands on their media and stakeholder relations. Media are both important stakekeepers and sources of information for other stakeholders. Therefore, we assume that individual-level perceptions of the media in relation to the organization are important factors in understanding stakeholder relations, but these perceptions have not been systematically analyzed and theorized. The present qualitative interview study focused on communication managers of Dutch independent administrative bodies. We developed a new conceptualization of media orientation and empirically explored how its dimensions are reflected in the managers' understandings of stakeholder relations. We found that communication managers try to cope with sector-specific challenges by implementing integrated communication strategies and exploring their communicative autonomy. Level of management support and incidents are key determining factors (Jacobs \& Wonneberger, 2019).

\section{METHODS}

This study uses a qualitative approach that seeks to track the communication process in decision making to choose Tionghoa Muslims from the Jakarta Lautze Mosque. Most of the Tionghoa Muslim residents are people who then open their hearts to accept the truth of Islam (converts). According to Taylor, Bogdan \& De Vault (2015), qualitative methods are research procedures that produce descriptive datain the form of written orspoken words from people and observable behavior. Qualitative research emphasizes inductive analysis, not deductive analysis. The data collected is not intended to support or reject hypotheses that were prepared before the research began, but abstractions are arranged as specificities that have been collected and grouped together through the process of collecting data that has been carefully implemented (Sutopo, 2006).

The focus of this research study is how the process of political communication in the decision making of Tionghoa Muslims in the Jakarta Lautze Mosque congregation in the 2012 DKI Jakarta Governor election. , Tangerang and Bogor. In addition they also have opinions and thoughts that are quite open in matters of government where this condition is hard to find in Tionghoa citizens who are not in community. The majority of Tionghoa Muslim worshipers in the Lau Tze mosque are business people from the middle to upper economic class. A total of 14 Tionghoa Muslims who were members of the Lau Tze mosque congregation and lived in Jakarta and had the right to vote in the DKI Jakarta Governor election were the subjects in this study. This is interesting because there are candidates who are ethnic Tionghoa but non-Muslim and on the one hand candidates who are Muslim but not of ethnic Tionghoa. This will certainly bring up the decisionmaking process that is interesting enough to be studied.

This study used a qualitative approach with in-depth interview techniques, especially to provide depth of information and analysis related to the decision-making process of Tionghoa Muslim citizens in the Lautze Mosque in the 2012 DKI Jakarta Governor election. In-depth interviews the interview guidelines do not contain questions that detailed, but only an outline of what data or information to obtain from the informant can later be developed by taking into account the development, context, and interview situation. Through in-depth interviews, the data obtained are qualitative data in the form of tangible collections of words and not a series of numbers. Qualitative data analysis conducted here is an analysis of the results of in-dept interviews which are answers to in-depth questions asked to informants. Data deemed less important is removed and not included in the results of the analysis. The data that is considered not important are for example answers from sources that are lacking depth, are not substantive, and answers which sometimes do not answer the question.

\section{RESULT AND DISCUSSION}

As stated at the beginning, this research intends to put forward the communication 
process in decision making in choosing among Tionghoa Muslim worshipers of the Jakarta Lau Tze mosque in the Election of the Governor of the Jakarta Special Capital Region (Governor election DKI) in 2012. The things that want to be tracked in this study will be seen from several important aspects, namely (a) from where (sources of information) regarding the 2012 DKI Jakarta Governor election obtained (b) what information about the 2012 DKI Jakarta Governor election (c) how the communication process happens up to the decision making stage.

Communication is considered as an intentional act (intentional act) to convey a message in order to meet the needs of communicators, such as explaining something to others or persuading him to do something. The conceptualization of communication as a one-way action highlights the effective delivery of messages and implies that all communication activities are instrumental and persuasive (Mulyana, 2007).

In the context of the delivery of political information about the 2012 DKI Jakarta Governor Election from political activists to the public, the prevailing framework for understanding communication is communication as the process of delivering messages and communication as a one-way action.

Every communication process must involve elements of communication. In this study the elements of communication involved consisted of: (a) the source of the message, the media used to obtain information about the 2012 DKI Jakarta Governor election both from mass media, interpersonal communication, and from other sources of information (b) message, namely information about the 2012 DKI Jakarta Governor election (c) recipients of the message, namely the Tionghoa Muslim community of the Jakarta Lautze Mosque, and (e) the effect, namely the decision to choose the Tionghoa Muslim community of the Jakarta Lautze Mosque.

1. Source of Information Regarding the 2012 DKI Jakarta Governor election
In relation to the DKI Jakarta Governor election, the mass media according to what McQuail (1996) revealed has a role as a source of information for Tionghoa Muslim groups in the Jakarta Lautze Mosque to obtain information on the 2012 DKI Jakarta Governor election. television then newspapers. The mass media is the dominant source of information compared to other sources of information that are also accessed by Tionghoa Muslim worshipers at the Lautze Mosque.

However, this does not mean that television is the only source of information accessed by Tionghoa Muslims in the Jakarta Lautze Mosque in an effort to obtain information/ knowledge about the 2012 DKI Jakarta Governor election. To a certain degree in other media such as newspapers, BBM (Blackberry Messenger), leaflets/ pamphlets, and billboards are also a source of information. In addition, information sources are also obtained through interpersonal communication processes with friends, family/relatives, groups/organizations, and also the head of the RT.

2. Information Regarding the 2012 DKI Jakarta Governor Election Obtained from Information Sources

Tionghoa Muslim congregation Lautze mosque get various kinds of information about the 2012 DKI Jakarta Governor election from the information sources they use. From the interviews conducted it can be seen that the information obtained by sources from the mass media (television and newspapers) is more on information about the characteristics of the candidate for the governor candidate which includes the profile of the governor candidate and the performance and achievements of the candidate. While from other sources of information theinformation obtained is also diverse. In addition to information 
about the profile and performance of candidates there is also information about the time and place of voting, jargon and vision and mission of the candidate, even negative information that badmouths certain candidates.

3. The Process of Political Communication in Making Decisions on Choosing Tionghoa Muslims

From the results of research conducted, it appears that the process of political communication is done through interpersonal communication, organizational/group communication, and mass communication. The process of political communication through some of the existing communication channels for some Tionghoa Muslims affects decision making and for some others it does not affect decision making. This is because Tionghoa Muslims do not only use one source/channel of information in making decisions. Besides that there are also Tionghoa Muslim citizens who precisely make their decisions not influenced by the existing communication process but due to other factors namely daily experience and ethnic/religious equality.

Every communication process must involve elements of communication. In this study the elements of communication involved consisted of: (a) the source of the message, the media used to obtain information about the 2012 DKI Jakarta Governor election both from interpersonal communication, group communication/organizational communication, and mass communication (b) message, namely information about the 2012 DKI Jakarta Governor election (c) recipients of the message, namely the Tionghoa Muslim community of the Jakarta Lautze Mosque, and (e) the effect, namely the decision to choose the Tionghoa Muslim community of the Jakarta Lautze Mosque.

As stated earlier, one of the objectives of this research is to find out how the process of political communication in the decision making of Tionghoa Muslim citizens in the Lautze Mosque in the 2012 DKI Jakarta Governor election. The diversity of sources of information and types of information obtained resulted in decision making that occurred was different different. In general, decision making is influenced by the source of information and the type of information obtained. Regarding the source and type of information obtained, the process of political communication in the decision making of the Tionghoa Muslim community in the Lautze Mosque can be categorized into four important points, namely the process of political communication through mass media, BBM, interpersonal communication, and group/organizational communication. In addition, how the influence of other factors related to decision making such as socio-cultural factors, opinion leaders, and the condition of Jakarta will also be presented as additional points that support the results of this study.

This decision making process will then also be related to how the political participation of Tionghoa Muslims in the Jakarta Lautze Mosque in the 2012 DKI Jakarta Governor election. To the communication process that occurs until they take the decision to choose a particular candidate or even do not use their voting rights.

Political participation as an activity of a person or group of people to participate actively in political life, among others, by choosing the leader of the state and directly or indirectly influencing government policy (public policy) (Budiardjo, 2003). Regarding how far the level of participation of Tionghoa Muslims in the Jakarta Lautze Mosque in the 2012 DKI Jakarta Governor election, from the research that has been done in general it can be seen that the support pattern of Tionghoa Muslim community supporters in the Jakarta Lau Tze mosque leads to Jokowi Ahok. This was seen from 14 Tionghoa Muslim residents who were the speakers, 8 of whom chose Jokowi Ahok, 4 people chose Foke Nara, and 2 people did not use their right to vote. 
The decision making process which is the effect of communication that occurs to a person after the process of receiving this message will be analyzed using AIDA theory which goes through four stages, namely Attention, Interest, Desire, and Action.

(a) Mass Media in the Decision Making Process

Early research in social psychology, political science, and communication continues to inspire the emergence of research agendas that seek and measure the influence of the media on their attitudes, opinions, beliefs in a potential process, which runs in a dynamic competition for sources (power and innate) are scarce especially during the election campaign period (Ghazali, 2004).

The influence of mass media on individuals can be through a onestep path (one step folow) and a two-stage pathway. The influence of communication through one stage (one step follow) where mass communication can affect individuals directly without going through an opinion leader or opinion leader. Whereas two step communication (Two step Flow) is a communication process when mass media influence individuals through opinion leaders. The twostage flow model is an effect-oriented study. The assumption of a two-stage flow model is that the effectiveness of mass communication occurs in the first stage through opinion leaders. Without the role of opinion leader, mass communication is very limited in its effectiveness on the audience. The next stage of opinion leaders will disseminate ideas that are understood from the mass media to the wider community (Tambunan, 2018).

In the 2012 DKI Jakarta Governor election, the mass media played a role in providing political information for Tionghoa Muslims, the Jamaze Mosque of the Lautze. It appears that not only information was provided, but the mass media also influenced the decision making for some Tionghoa Muslims from the Lautze Mosque. The mass media, especially television does have the power to influence the audience, including in this case the influence in decision making. Even for some Tionghoa Muslims who only use the mass media as their only source of information, the influence of the mass media is very obvious because they do not get comparative information from other sources.

"Iya dong. Jelas itu dari media massa. Jokowi figur yang sangat dirindukan oleh masyarakat. Ini baru I, 2, yang muncul kan. Nanti akan banyak lagi yang muncul. Insting itu muncul karena lihat berita. Lihat profilnya, kesederhanaannya." (Ahui, personal communication. 2012, October 27)

"Ya karena Faisal Basri gagal di putaran pertama. Sehingga ganti halauan milih Jokowi, karena lihat debatnya. Dari kemampuan mentalnya menjawab saat debat pilgub. Cara dia menjawab, cara dia mengungkapkan, cara dia mengutarakan pendapat, itu kan dinilai semua." (W.Prasodjo, personal communication. 2012, October 28)

This is in line with research findings of Joko (2016), that the credibility of a religious symbolic leader is strongly influenced by the news conveyed by the mass media. This study discusses the credibility of KH. Fuad Amin, a religious symbolic figure who was involved in a corruption case. From the results of the calculation of the statistical tests conducted showed that there was a significant influence on the reporting of corruption cases KH. Fuad Amin on the credibility of religious symbolic leaders.

From this it is known that the decision making process through mass communication is in accordance with the steps in the AIDA theory in full. Informants through the stages 
of attention (attention) by starting to choose, know and understand an information received, become aware of and know the presence of Jokowi as a candidate for governor of DKI. Furthermore, after going through the attention stage, the informant goes through the interest stage, which is the stage where the informant starts to be interested in knowing more about Jokowi, Jokowi's excellence, whether it is in line with their expectations. At this stage a person is no longer passive in his consciousness, but has begun to actively consider the good for himself when choosing Jokowi. And in the third stage, the informant has reached the stage of desire (interest) which is the stage where the informant has begun to determine his attitude towards a candidate he likes, namely Jokowi. Matches began to emerge with his needs, necessity and confidence to choose Jokowi compared to other candidates. And at the last stage, action is the stage where someone chooses the partner Jokowi Ahok.

In connection with the 2012 DKI Jakarta Governor Election, most of the audiences exposed to the media (television) who reported a lot about the profile and performance of Jokowi who were achievers also finally made the decision to choose Jokowi after seeing his profile through mass media.

In conditions where decision making is not influenced by the mass media, the stages in AIDA theory do not apply fully. The informant only reaches the attention stage by paying attention to information about the Jakarta governor election but not to the next stage until the decision making action from the information obtained. Actions in decision making are precisely influenced by factors outside the mass media.

The decline in the notion that the mass media has enormous power in influencing audiences, began with the research conducted by Paul Lazarsfeld and his colleagues in 1940. This research was conducted to determine the effect of mass media in election campaigns on voting behavior. What Paul Lazarsfeld found (Rakhmat, 2004) is surprising, especially after audiences have known the Bulletory Theory, namely that: (1) mass media has almost no effect at all; (2) Mass media is considered to be more functioning to strengthen existing beliefs; (3) interpersonal media is more dominant than mass media; (5) audiences filter information through a process called selective exposure and selective perception (Widowati, 2012).

(b) Interpersonal Communication in Decision Making

Apart from the mass media, TIonghoa Muslim congregants from the Lautze Mosque also received information about the Jakarta governor election through interpersonal communication. This communication process is carried out both with family/ relatives, RT heads, and friends. In the end what happens is not only the information transfer process, but also the mutual influence of the decision making process in the communication.

Information obtained through interpersonal communication with close people as well as people who are already known to have more influence than information that is only obtained from the mass media. Information obtained from the mass media for some Tionghoa Muslim worshipers in the Lautze mosque only has a limited role in enriching knowledge about the Jakarta governor election while information obtained from interpersonal communication with close people to the stage influences the decision making process in the Jakarta governor election conducted.

"Tadinya aku golput di putaran pertama. Diputaran kedua aku milih yang muslim, Foke. Akhirnya yang 
nguatin aku teman. Sama keyakinan aku juga sih. Teman nasehatin juga. Aku juga parno kalo sama yang berkuasa non muslim gitu. Saya dikasih ayat nih. Intinya Al Maidah ayat 51. "(Dinar, personal communication. 2013, March 2)

"Ketua RT ngomong ke saya untuk menggunakan hak pilih dan mengarahkan juga untuk milih yang bebas partai politik. Independent. Karena ini pertama kali ada yang independent. Dari pak RT yang memantapkan. Saya kan dekat dengan pak RT jadi ya saya ikuti sarannya.." (W. Prasodo, personal communication. 2012, October 28)

People close to the head of the RT through persuasion and information provided are able to influence the decision making process. Interpersonal communication with family/relatives also influences the decision making process.

This is in line with Ella Handayani's research which shows that leadership and interpersonal communication have a significant positive effect on the decision making process in realizing employee performance improvement. To be able to produce a good decisionmaking process can be done by perceiving leadership positively and mobilizing optimal interpersonal communication so that the employee's performance improvement is optimally realized (Handayani, 2014).

For some Tionghoa Muslims the Lautze Mosque congregation does not always affect interpersonal communication in the decision making process. In the case of the informant, the stages in the AIDA theory do not apply fully. Informants are limited to the stages of attention by getting and giving attention related information about Ahok. The inerest and desire stages are not passed while the action stage is precisely influenced by daily experience when seeing firsthand the condition of Jakarta.

(c) Organizational / Group Communication in Decision Making

"Interpersonal" communication channels, "organizational channels", for example political parties, interest groups and mass organizations that have specific goals must be used to gain mass support (Baran, Shanock, Miller, 2012). The field of group communication studies basically learn the patterns of interaction between individuals in a social group (usually small groups and not mass groups), with a particular emphasis, for example decision making. This tendency is based on the belief that personal decision making, for example when someone has to make choices among possibilities, is different from the decisions that must be made together in a group. This difference is mainly due to the intertwined relationships between individuals in the group with all the consequences that accompany it such as differences in economic classes, social classes, interests, knowledge, perceptions and attitudes.

In fact, some Tionghoa Muslims from the Jakarta Lautze Mosque are not only members of the Jakarta Lautze Mosque community. Some of them are also members of organizations/groups outside the Jakarta Lautze Mosque congregation as if they are part of political parties or kinship groups. It is undeniable that those who join the organization/groupalso carry out group communication to obtain information about the Jakarta Governor Election from the organizations/groups that are followed. Even this information affects the decision making process. Loyalty to the organization/group that was followed made it follow the policies set by the organization/group in making decisions at the 2012 DKI Jakarta Governor election. This happened to Evi (32, female, housewife) who was a 
cadre of a political party (PKS/Partai Keadilan Sejahtera) which sets its vote on Foke because there is already an appeal from PKS so that the cadre's voice is directed to Foke at the DKI Jakarta Governor election.

"Awalnya kalau kita tetap bapak Hidayat Nur Wahid. Kemudian pada putaran kedua kalau saya lebih karena sudah ada keputusan dari Dewan Syuro PKS suara diarahkan ke Foke jadi ya saya pilih Foke. "(Evi, personal communication. 2013. March 2)

It is undeniable that a person joins the group because of the similarity of background and vision in the future. Like Eko Putro Adi Purnomo (52, male, spiritual teacher) who is a member of the Student Army Family group where Ahok is also a member. The existence of this group bond then made the interviewees give their votes to the Jokowi Ahok couple.

"Waktu itu Ahok datang ke acara Tentara Pelajar karena mau ikut 17an saja.. Ya karena kami sama-sama dari Keluarga Tentara Pelajar juga jadi ya istilahnya sesama saudara sendiri kan ya mesti bantu." (A. Purnomo, personal communication. 2013, March 2)

The structuration approach, for example, suggested by Marshall Scott Poole et al; view group communication for decision-making efforts as a process whereby individual members strive for mutual agreement (convegerance) or agreement (agreement) on or regarding final decisions and how they structure their social systems. This means that individuals in the group express their opinions and desires with which then formed and re-formed certain provisions or rules (rules) that can lead them to a togetherness or maybe the opposite judge, according to the possibility of achieving togetherness (Littlejohn \& Foss, 2009). In this connection there are at least three elements of action that play a major role, namely (a) interpretation of the messages used or to be delivered, (b) morality-derived from the norms that apply or are adopted in society, and (c) power (power) that develops because of the structure of interpersonal relationships.

In the case of the Evi informant as part of the PKS organization, the opinion of Marshall Scott Poole et al; not entirely valid because in decision making it does not involve the opinions of party cadres. In the PKS the decision to choose is carried out by the Syuro Council, which is a group of people who are a structure in the party and are given the authority to take every decision of the PKS organization. Henceforth all party cadres followed the decision of the Syuro Council in making its decision.

It is true that loyalty to an organization influences the political decision making process. Especially if the organization is active or engaged in politics, of course the political tendencies of its members cannot be separated from the political tendencies of the organization. This is also true for some Tionghoa Muslim worshipers in the Jakarta Lautze Mosque. Although they get information from outside the organization/group, in the end loyalty to the organization/group is more dominant in the political decisionmaking process in the 2012 DKI Jakarta Governor election.

(d) Sociocultural Factors in the Decision Making Process

The decision making process in the 2012 DKI Jakarta Governor election certainly involves many factors, one of which is the socio-cultural factor. In this case the sociocultural factors in question are religion and ethnicity. The existence of similarities or differences in religion and ethnicity may influence the decision making process for 
Tionghoa Muslims in the Lautze Mosque. For some Tionghoa Muslims, ethnic similarity influenced him to vote for the candidate. Susanto said that the results of the Reform Institute survey which were widely publicized by the media in early July 2008, in determining the choice of candidates, voting choices were based on (1) Religious Equity: $33.76 \%$, (2) Suggestions of $28.51 \%$, (3)) Supporting Party: $28.13 \%$. In addition, related to civil or military, around $60.12 \%$ did not question the military or civilians. While related to ethnic issues, 65.48 respondents did not question Java or Non-Java. The composition of respondents' answers shows freedom of expression in general elections that go towards state democratization (Susanto, 2013)

Some Tionghoa Muslim members of the Lautze Mosque worship some who consider the issue of ethnic equality and some consider religious equality. For example, Dinar (28/female/PAUD teacher) who no longer considers ethnic equality in the decision making process but rather looks at the similarities religion with candidates.

"Aku sebenarnya nggak masalah milih siapa. Yang penting muslin kalo bagi aku. Tadinya aku golput di putaran pertama. Diputaran kedua aku milih yang muslim, Foke. "(Dinar, personal communication. 2013, March 2)

Social identity is formed from the involvement, caring, and pride of individuals as part of the social group under their care (Hogg, Abrams, Otten, Hinkle, 2004). In this case the social identity is still very high where the informant deliberately participates, and develops a sense of care and pride for the group. Jakarta Tionghoa Muslims who chose the Jokowi Ahok couple because there were ethnic similarities with Ahok, namely ethnic Tionghoa. Or choose Foke Nara because of the similarity of Islam with the candidate.
In the condition of the informants above, the political theory of ethnic identity also applies because the informant chooses candidates who have religious and ethnic similarities. The decision making at the DKI Jakarta Governor election was based on ethnic and religious factors. In the theory of enicity, seen from the primordialism approach, it appears that the personal, primordial, and sacred ties. it still survives in a modern world. This approach assumes that social groups are characterized by regional, religious, cultural, linguistic, and social organization images that are objectively recognized as indisputable.

This is different from some other sources. For some Tionghoa Muslim congregation Lautze Mosque, the differences/similarities in religion and ethnicity do not affect the decision making. For example, Amin Ali Nurdin (49, male, businessman) who chose Jokowi Ahok was not because of ethnic similarities with Ahok but rather on the figure of Jokowi who was considered capable of bringing about change because Jokowi was a successful businessman. Because for Tionghoa citizens economic progress is more important than ethnic similarity.

"Mungkin Betawi memiliki panutannya, Jawa memiliki panutannya. Cuma China yang nggak ada panutannya. Panutannya China ya ekonomi. Kita lebih melihat dari segi ekonomi sebagai panutan. Kalau situ maju secara ekonomi ya jadi panutan lah. Jokowi di mata China itu maju. Ahok di mta orang China itu nggak ada apa-apanya. Kelasnya beda. Di Chinese maju ekonomi disitulah dipilih."( A.A. Nurdin, personal communication, 2012, October 27)

Related to the influence of sociocultural factors in the decision making process for Tionghoa Muslims, the Jamaze Mosque of the Lautze Mosque is indeed quite interesting. Some pilgrims 
are affected by socio-cultural factors in decision making and some are not affected. This was conveyed by Yusman (53, male, organizer of the Lautze foundation) who said that related to sound mapping and decision making was quite a dilemma among Tionghoa Muslims in the Jakarta Lautze Mosque congregation.

"Ya memang itu agak dilematis ya bagi teman-teman kita yang muslim China. Mungkin kalau di pak Jokowi nya tidak masalah. Beigitu berpasangan dengan Ahok ya disitulah dilematisnya pilihan. Disatu sisi ingin mempertahankan keyakinan bahwa pemimpin harus muslim disisi lain mereka juga ingin kebanggaan kalau satu etnis yang baru bisa muncul jadi pejabat. "Yusman, personal communication. 2013, March 1)

On the other hand M. Ali Karim (57, male, head of the foundation) said that ethnic and religious factors had no effect on the decision making process for Tionghoa Muslims in the Jakarta Lautze Mosque congregation because of the community (in this case Tionghoa jama'ah Muslim Mosques Lautze Jakarta) looks more at performance issues not on ethnic or religious factors.

"China itu salah satu etnis. Orang China sukunya juga banyak. Ada ratusan suku di China. Ahok mungkin suku apa, nah, suku lain juga nggak mau. Bukan juga karena sama-sama China.Belum tentu. Jadi sekarang ini berbicara Pilkada orang ngelihat bukti lah, bukan janji." (M.A Karim, personal communication. 2012, October 27)

From the interviews that have been carried out, it can be concluded that the socio-cultural factors have an influence in the decision making process for Tionghoa Muslims but on the one hand also has no influence. This happens because every Tionghoa Muslim congregation in the Lautze mosque has a different perception in seeing the religion or ethnicity of the
Jakarta governor candidate.

(e) The Role of Opinion Leader

The concept of 'opinion leaders' in traditional media, they can express their opinions by using mass media channels. For example, Lazarsfeld, Berelson, and Gaudet (1948) suggested that 'opinion leaders', who actively collect information sent from the mass media, incorporate their own values and views into the information, and then pass it on to consumers around them in daily life (Hananto, 2014)

In relation to the 2012 DKI Jakarta Governor Election which leads to political decision-making, the opinion of group leaders can influence the decision-making process. A leader certainly has the authority and potential for his opinion followed by its members. Including his decision in providing voting support for certain governor candidates in the 2012 DKI Jakarta Governor election, it is very likely that members will participate. It could even be the group leaders calling on their members to vote for certain candidates in the 2012 DKI Governor election. However this did not happen to the leaders of the Jakarta Lautze Foundation in the Jakarta Governor Election event. There is no appeal or direction from the leadership of the foundation for its members to provide support to certain candidates. Even those who are majority converts (converting religion from non-Muslims to Muslims) did not then try to find out how the opinion of the foundation leadership or religious teacher in the 2012 Jakarta governor election event related to the candidate that must be chosen. Residents of Tionghoa congregation Jakarta Lautze Mosque chose to avoid openly discussing politics in the mosque. For them the mosque is a place of worship. Even with regard to opinion leaders, both the leadership of the foundation and the mosque cleric, 
they are not a separate consideration in making political decisions.

M. Ali Karim (57, male, general manager of the foundation) said that there was noappeal from the foundation to elect certain candidates, all returned to their respective personalities.

"Semuanya bersikap masing-masing. Karena inilah demokrasi. Kebebasan. Tidak ada juga ustadz semacam itu. Himbauan kita juga tidak ada. Karena kita tidak berpolitik. Ya memang kebanyakan pada kesini. Karena memang lau Tze tidak berpartai. Jangan bawa partai kemari.. Dan disini juga nggak ada kampanye Kita anjurkan jangan masjid ini untuk kampanye. Kalau masjid lain sih bebas-bebas saja. Jadi kita sendiri tidak berpolitik tapi kalau ustad saya segala macam bebas. Semuanya masing-masing. Ada yang PKS, ada yang Golkar, ada yang Demokrat, semuanya masingmasinglah" (M.A. Karim, personal communication. 2012, October 27)

In the decision-making process of the Tionghoa Muslim community the Lautze Mosque did not find any influence from opinion leaders. In general, the informants making decisions were not then associated with their status as pilgrims to the Jakarta Lautze mosque but more on other considerations. Because indeed the fact is there is no appeal from the leadership of the foundation or religious teacher and Tionghoa Muslims also consider the mosque as a place to worship, not for politics. This is the case with Anastasya (45, woman, housewife) who chose Jokowi Ahok not because of an appeal from the leader of the foundation/ cleric foundation.

A similar statement was also conveyed by Eko Adi Purnomo (52, male, spiritual teacher) who said that the discussion regarding the Jakarta governor election and the appeal/ direction from the leadership he did not find at the Lautze Mosque.
"Masjid murni untuk ibadah ya nggak berpolitik di sini. Kalau mau berpolitik di luar sana. Kayak saya ikut groupnya Ahok juga di luar nggak saya ajak juga orang di sini buat milih Ahok, disini murni ibadah. Ustad juga nggak pernah ajak-ajak kita untuk dukung siapa. Kembali ke personalnya ya."(E. A, Purnomo, personal communication. 2012, March 2)

Lautze is a foundation whose membership is not tied up so that Tionghoa citizens of the Lautze Mosque are not officially registered as members of the foundation. This is in contrast to organizations that are administratively binding in nature. Evi (32, woman, housewife) also felt that membership in Lautze was more relaxed because they were not organizations so that in the political decision-making process in the 2012 DKI Jakarta Governor election there was also no direction or appeals from the leadership of the foundation.

"Kita disini kan nggak boleh bawa bendera ya. Artinya kita disini tidak boleh membahas partai tapi lebih kepada para muallaf yang mau belajar. Terus kalau dari ketua masjid tidak ada pengarahan atau sosialisasi untuk milih siapa gitu. Beda kalau di PITI, di PITI ada pengarahan kita besok milih ini ya.." (Evi, personal communication. 2013, March 2)

In connection with this research, it can be seen that the socio-cultural conditions between the Tionghoa Muslim community of the Lautze Mosque and the leaders of the foundation and with the cleric of the mosque have no gaps. The Muslim congregation of TIonghoa Lautze Mosque in general can be seen from the upper middle class people who have an adequate level of economy and education. This is one of the factors that they have independence in their political attitudes. Tionghoa Congregation Lautze Mosque has a political character that is not the same 
as other Tionghoa citizens. They are more open to express their opinions and have their own independent attitude in political activities. This has caused the influence of opinion leaders not to apply to Tionghoa Muslims in the Jakarta Lautze Mosque congregation in making political decisions regarding the 2012 DKI Jakarta Governor election. In addition, the majority of Tionghoa Muslim followers in the Jakarta Lautze Mosque are mostly urban people who access the mass media. They tend to have a high need for mass media so that they directly access it without using an intermediary opinion leader because in general they are modern urban society who are technology and information literate. Not found the influence of opinion leaders in this research because also the Lautze Foundation and the Lautze Mosque congregation do not carry political flags in their religious activities. Political matters are returned to the individual, whereas the mosque is more optimized for the function of worship.

In other studies also mentioned that the role of opinion leaders is very lacking and passive in problems in the community such as individualism of the community, slow development, and unequal information in the community

Tionghoa Muslim community members of the Lautze Mosque get a lot of information from various sources of information where some of the information obtained will influence the decision making process. In addition to getting information from the mass media, the interpersonal communication process and from other sources, some of the speakers also went through daily experiences by seeing the current condition of Jakarta. The reality of Jakarta which still needs improvement is a separate factor that also influences the decision making process in the 2012 Jakarta Governor
Election.

Some Tionghoa Muslims feel that the DKI Jakarta governor does not need to change. Let Fauzi Bowo (Foke) continue the development policy that has already begun. Because seeing the real conditions of Jakarta everyday, Lani Ridwan (55, woman, housewife) decided to choose Foke in the hope that Foke could complete the construction that had already begun.

"Putaran pertama milih Foke. Putaran kedua juga Foke. Saya anggap dia lebih berpengalaman. Lebih dewasa. Dan biarkan menghabiskan masa jabatannya lima tahun lagi." (Lani, personal communication. 2012, October 28)

The same thing was also conveyed by Lia (27, female, private employee) who chose Foke as well because they saw first hand the condition of Jakarta and expected Foke to complete the policies he had made.

"Kalau putaran pertama milihnya Fauzi Bowo, yang kedua, setelah baca-baca itu, pilihannya juga tetap Fauzi Bowo. Karena kalau saya lebih percaya kalau incamben saja. Karena kalau masih ada waktunya diteruskan dulu. Karena menurut saya lima tahun itu waktu yang sangat sedikit untuk melakukan kebijakan-kebijakan.." (Lia, personal communication. 2013, March 2)

The experience of the interviewees, in this case the experience of Tionghoa Muslims in the Jakarta Lautze Mosque congregation who are Jakarta residents of the reality of the city of Jakarta to the daily conditions of Jakarta is a separate factor that will influence decision making in choosing. This is as explained in the theory of cognitive dissonation introduced by Leon Festinger in 1957.

According to Festinger, cognitive dissonance theory has important implications in many specific situations (Shaw \& Constanzo, 1982). Festinger outlines the implications of decisions, 
forced compliance, information seeking (exposure to information), and social support.

In connection with the decision making to choose Tionghoa Muslims in the Jakarta Lautze Mosque, a dissonance was found where information about the condition of Jakarta obtained from daily experiences during life in Jakarta made the resource persons choose incumbent candidates or rather choose not to use their right to vote ( abstentions). The reason for choosing an incumbent candidate is because of the desire that the previous governor completed the construction which had begun during his tenure. While abstentions arise because of the pessimistic attitude of Tionghoa Muslims about the ability of the candidate for governor to bring Jakarta to a better direction.

Abstentions have been an interesting political phenomenon in Indonesia since the 1970s. This is because abstentions are not only interpreted as voters who do not exercise their voting rights but have become a political movement which in Indonesia is driven by Arief Budiman who voiced a scathing reaction towards the new order regime which was judged in the implementation of undemocratic elections. The originators of this group called for voters not to exercise their right to vote in the General Election because they saw that voting meant the election process was legalized.

Lilis Kurnia (49, woman, housewife), for example, chose not to use her right to vote because it was the same as seeing that conditions in Jakarta had not changed for the better year after year.

"Ibu nggak milih.. Pusing mau milih siapa. Sama aja begini nggak berubah. Saya nggak milih, saya nggak mau ribet. Pusing. Terpilihnya Foke kek, pak Jokowi kek, sama saja. Saya sudah nggak mau milih. Nggak ada perubahan juga. Berubah nggak? Nggak kan." (L.
Kurnia, personal communication. 2013, March 1)

The same thing was done by Naga (32, male, businessman) who chose to abstain because he saw the condition of Jakarta that has not changed. Although there are elections that will give birth to new leaders, the interviewees are not sure that the new leaders will be able to fix Jakarta.

"Ya terkesan agak pusing aja gitu. Karena kita di Jakarta kan bukan setahun dua tahun ya. saya lahir kan juga di Jakarta. Tapi perkembangan ibu kota Jakarta makin lama bukan makin terarah tapi makin semrawut. Kemacetan di mana-mana. Dan dari sisi keamanan juga sampai sekarang Jakarta juga nggak aman. "(Naga, personal communication. 2012, October 29)

By looking at Jakarta's direct conditions, it will raise its own considerations for Muslim citizens of the Lautze Mosque in making decisions. Some speakers want incumbent candidates (Foke) to be elected and continue their government while some other speakers choose to abstain because of the election that will give birth to new leaders will not be able to change the condition of Jakarta better.

(f) Rationality of Voters in Making Voting Decisions

From the research that has been done in general, it can be seen that Tionghoa Muslims from Jakarta Lautze Mosqueare rational in using theirvoting rights in the 2012 DKI Jakarta Governor election. This can be seen from the rational decision making process because it does not get interference (pressure) from other parties. Even if there is influence from the closest people, groups/organizations, then it does not come to the form of threat that makes the decision to be irrational. All decisions choose to return to each 
individual where the intrapersonal communication process takes place in it when someone then considers with full awareness of how the decision to choose will be taken.

This is different from Arga Sevtyan's research findings regarding voter behavior in the Trenggalek community. The "gossip" behavior is a unique finding in expanding about the study of voter behavior. The attitude of "gossip" in Javanese philosophy means being easily amazed and surprised at the wealth, intelligence, nobility of others. In the context of the Trenggalek Regional Election, voter behavior means that the public tends to be easily impressed by the campaign promises and external appearance of the candidate but is unable to judge whether it is rational or not for welfare. (Vallentyno, 2018)

The rational actions of the Tionghoa Muslim community in the Jakarta Lautze Mosque in making the decision to vote can also be related to the character of the voting community which belongs to the category of urban society and modern society. Modern society tends to be more rational in determining decision making besides the decision to vote in the scope of general elections is the democratic right of each voter audience without pressure from other parties.

\section{CONCLUSION}

In making the decision to choose, the Tionghoa Muslim community of the Jakarta Lautze Mosque through several communication processes, namely communication through mass media, communication with BBM (Black Berry Massanger), interpersonal communication, and group / organizational communication. For the majority of Tionghoa Muslim congregation Lautze Mosque information obtained from the mass media is more on increasing knowledge about the 2012 DKI Jakarta Governor election, not to have an effect on decision making. Although for some residents the information obtained from the mass media is also influential, but it is not dominant in all interviewees. Whereas the communication process carried out through BBM (Black Berry Massanger) media is more on discussion activities (persuasion and argumentation) related to governor candidates whoare devoted but do not havean effect on decision making because everything is returned to their respective personalities. On the one hand precisely interpersonal communication with friends, and relatives communication conducted with groups outside the congregation Lautze Mosque precisely gives a dominant influence on decision making to choose Tionghoa Muslims in the Lautze Mosque congregation. In general, socio-cultural (ethnic and religious) factors did not influence the decision making for Tionghoa Muslims in the Jakarta Lautze Mosque. Although for some informants this factor is also a consideration in decision making. The citizens are rational enough to choose a leader without considering the sociocultural factors. In this study, there was no influence of opinion leaders (in this case the mosque cleric and the leader of the Lautze foundation) in the decision to choose Tionghoa Muslims from the Lautze Mosque in the 2012 DKI Jakarta Governor election. This is because Tionghoa Muslims from the Lautze Mosque separate between religious affairs and political affairs. The mosque is more focused on worship activities only, not to discuss political issues.

\section{REFERENCES}

Afif, A. (2012). Identitas tionghoa muslim Indonesia. Depok: Kepik

Alfian, M. A. (2013). Menjadi pemimpin politik. Jakarta: Gramedia Pustaka Utama.

Amirudin, Z. (2016). Model communication enggagement dalam komunikasi politik calon legislatif dalam pemilu umum 2014. Informasi, 45(2), 115-124. https:// doi.org/10.21831/informasi. v45i2.7987

Baran, B. E., Shanock, L. R., \& Miller, L. R. (2012). Advancing organizational 
support theory into the twenty-first century world of work. Journal of Business and Psychology, 27(2), 123-147.

Budiardjo, M. (2003). Dasar-dasar ilmu politik. Jakarta: Gramedia pustaka utama.

Christian, S. A. (2017). Identitas budaya orang tionghoa Indonesia. Jurnal Cakrawala Mandarin, 1(1), 11-22. https:// doi. org/10.36279/apsmi.vii1.11

Darini, R. (2008). Nasionalisme etnis Tionghoa di Indonesia: 1900-1945, Mozaik, 3(1).

Eriyanti, F. (2006). Dinamika posisi identitas etnis Tionghoa dalam tinjauan teori identitas sosial. Demokrasi, 5(1), 23-34.

Ghazali, E. (2004). Interaksi politik dan media: dari komunikasi politik ke politik komunikasi. Jurnal Ilmu Sosial dan Ilmu Politik, 8(1), 53-74.

Hananto, P. (2014). Opinion leader versus new opinion leader dalam komunikasi pemasaran (studi kasus selebtwit di twitter untuk komunikasi pemasaran). Interaksi: Jurnal Ilmu Komunikasi, 3(2), 140-153. https://doi. org/10.14710/ interaksi,3,2,140-153

Handayani, E. (2018). Pengaruh kepemimpinan dan komunikasi interpersonal terhadap proses pengambilan keputusan dalam mewujudkan peningkatan kinerja pegawai. Jurnal Publik: Jurnal Ilmiah Bidang Ilmu Administrasi Negara, 12(01), 24-32.

Hogg, M. A., Abrams, D., Otten, S., \& Hinkle, S. (2004). The social identity perspective: Intergroup relations, selfconception, and small groups. Small group research, 35(3), 246-276.

Imran, H. A. (2012). Media massa, khalayak media, the audience theory, efek isi media dan fenomena diskursif. Jurnal Studi Komunikasi dan Media, 16(1), 47-6o. https://doi.org/10.31445/ jskm.2012.160103
Jacobs, S., \& Wonneberger, A. (2019). Dealing with increasing complexity: Media orientations of communication managers in public sector organizations. International Journal of Communication, 13, 918-937.

Kodiran, M.A. (2012).Asimilasi etnistionghoa indonesia dan implikasinya terhadap integrasi nasional (studi di kota tanjungbalai provinsi sumatera utara) (Doctoral dissertation, [Yogyakarta]: Universitas Gadjah Mada).

Kononova, A., \& Akbar, M. (2015). Interpersonal communication, media exposure, opinion leadership, and perceived credibility of news and advertising during the december 2012 parliamentary election in Kuwait. International Journal of Communication, 9(1), 1206-1228.

Lampe, I. (2014). Identitas etnik dalam komunikasi politik. Jurnal Ilmu Komunikasi, 8(3), 299-313.

Littlejohn, S. W., \& Foss, K. A. (2009). Encyclopedia of communication theory (Vol. 1). Sage.

McQuail, D. (2011). Teori komunikasi massa, Jakarta; Salemba Humanika.

Mulyana, D. (2007). Ilmu komunikasi. Bandung: Remaja Rosdakarya.

Prasetyo, I.J. (2016). Pengaruh pemberitaan media massa terhadap kredibilitas pemimpin simbolik keagamaan. Jurnal Komunikasi Universitas Tarumanegara, 8(2),159-169.

Rakhmat, J. (2004). Komunikasi politik, komunikasi pesan dan media. Bandung: PT Remaja Rosdakarya.

Shaw, M. E., \& Costanzo, P. R. (1982). Theories of social psychology. New York: McGraw Hill.

Surbakti, R. (1992). Memahami ilmu politik. Jakarta: Grasindo.

Suryadinata, L. (2010). Etnis Tionghoa dan nasionalisme Indonesia: sebuah bunga 
rampai, 1965-2008. Jakarta: Penerbit Buku Kompas.

Susanto, E. H. (2013). Dinamika komunikasi politik dalam pemilihan umum. Jurnal Kajian Komunikasi, 1(2), 163-172. https://doi.org/10.24198/jkk.volın2.6

Sutopo, H. B. (2006). Metode penelitian kualitatif: Dasar teori dan terapannya dalam penelitian. Edisi-2. Surakarta: Universitas Sebelas Maret.

Tambunan, N. (2018). Pengaruh komunikasi massa terhadap audiens. JURNAL SIMBOLIKA: Research and Learning in Communication Study, 4(1), 24-31.

Tan, A. S. (1985). Mass communication theories and research. New York: Wiley.

Taylor, S. J., Bogdan, R., \& DeVault, M. (2015). Introduction to qualitative research methods: A guidebook and resource. New York: John Wiley \& Sons.

Vallentyno, A. S. (2018). Perilaku gumunan: Rasionalitas semu pemilih jawa (temuan awal). CosmoGov: Jurnal Ilmu Pemerintahan, 4(1), 106-118. https://doi. org/10.24198/cosmogov. v4i1.16224

Widowati, D. (2012). Efek media massa terhadap khalayak. Jurnal Adzikra, $3(1), 75-98$. 